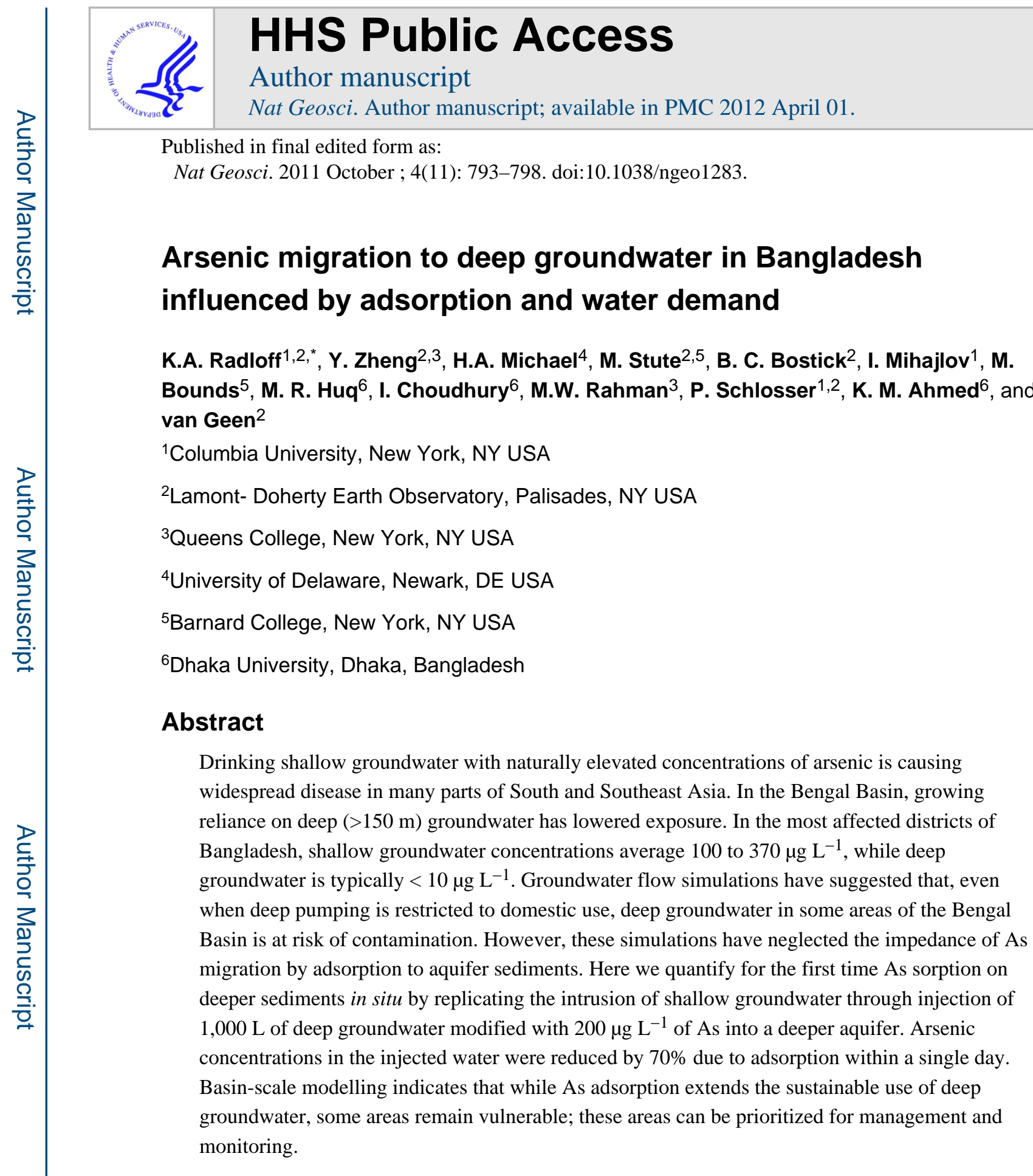

Users may view, print, copy, download and text and data- mine the content in such documents, for the purposes of academic research, subject always to the full Conditions of use: http://www.nature.com/authors/editorial_policies/license.html\#terms

Correspondence and requests for materials should be addressed to K. A. Radloff.

* K.A. Radloff is now at Gradient Corporation, Cambridge, MA USA.

Author Contributions: K.A.R, Y.Z, M.S, K.M.A and A.v.G designed the adsorption studies. K.A.R., M.S., I.M. and Y.Z. conducted the push-pull experiments. Y.Z. conducted the batch adsorption experiments. H.M. designed and executed the hydrological model of the Bengal Basin. I.M, M.B, M.R.H, I.C, M.W.R. provided field and laboratory assistance for the adsorption experiments. B.B. provided sediment mineralogical analysis. P.S. advised and supported the work of K.A.R. K.A.R, Y.Z., and H.M. analyzed the data and wrote the paper, which was then edited by A.v.G.

Competing Financial Interests statement: The authors declare no financial interests. 
Elevated groundwater As concentrations are common within the upper $100 \mathrm{~m}$ of aquifer systems throughout South and Southeast Asia ${ }^{1,2}$. With the exception of its westernmost portion in the Indian state of West Bengal and the Sylhet Basin of Bangladesh, the As content of groundwater in the Bengal Basin at depths greater than $150 \mathrm{~m}$ is mostly $<10 \mu \mathrm{g}$ $\mathrm{L}^{-1}$, the World Health Organization's (WHO) drinking water guideline value ${ }^{2-4}$. In Bangladesh, the installation of over 100,000 deep wells that are low in As ${ }^{3,5,6}$ has helped lower As exposure, but the vast majority have not been monitored over time ${ }^{7}$. At the same time, withdrawals for the municipal supply of large cities and concerns about the prolonged use of high-As water for irrigation ${ }^{8}$ have increased demand for deeper groundwater ${ }^{9}$. Recent surveys of deep (>150 m) hand-pumped wells have shown that a worrisome 14 to $18 \%$ of those in Bangladesh ${ }^{3,10}$ and $25 \%$ of those in the four most contaminated districts of West Bengal ${ }^{11}$ contain As at concentrations $>10 \mu \mathrm{g} \mathrm{L}{ }^{-1}$. The proportion of larger-scale public water supply systems drawing from deeper aquifers $(>150 \mathrm{~m})$ in West Bengal that do not meet the WHO guideline for As is even higher ${ }^{12}$. It is unknown to what extent these observations reflect localized failures due to poor well construction, naturally occurring groundwater As at depth or, more troubling, the broad-scale contamination of deep groundwater from shallow sources. Previous groundwater flow simulations indicate that widespread contamination of deep groundwater may result from deep pumping for irrigation and some areas may even become contaminated when pumping is only for domestic use ${ }^{13}$. The adsorption of As onto iron minerals present in the sediment ${ }^{14-16}$ could impede As transport into the deeper aquifers from intruding shallow groundwater, but adsorption properties have not been well characterized for deeper sediments in Bangladesh under realistic conditions ${ }^{17}$. The present study provides in situ measurements of As adsorption and directly addresses concerns about broad-scale contamination by presenting a new spatially resolved estimate of the vulnerability of deep groundwater throughout the Bengal Basin.

\section{Measuring As adsorption}

Our study site $\left(90.6^{\circ} \mathrm{E}, 23.8^{\circ} \mathrm{N}\right)$ is located in the fluvial floodplain of central Bangladesh. Here groundwater As concentrations are elevated within the shallow, gray sands, reaching $210 \mu \mathrm{g} \mathrm{L}{ }^{-1}$ at $38 \mathrm{~m}$ depth ${ }^{18}$. Below $50 \mathrm{~m}$ lie brown sands characteristic of partially reduced Fe oxides that are associated with very low $\left(<2 \mu \mathrm{g} \mathrm{L}^{-1}\right)$ As concentrations in groundwater ${ }^{9}$. There is no low-permeability clay layer separating the two layers. A distinguishing feature of this study is that As adsorption parameters in the low-As aquifer were determined from both in situ experiments and batch As adsorption experiments. In situ estimates were derived from push-pull tests, where low-As groundwater was pumped from the brown sands and immediately injected into a nearby well at the same depth after adding $\sim 200 \mu \mathrm{g} \mathrm{L}-1$ of $\mathrm{As}(\mathrm{III})$ or $\mathrm{As}(\mathrm{V})$ and bromide as a conservative tracer. The extent and rate of adsorption of both As species onto aquifer sands was determined by stepwise pumping of the injected water and measuring its loss of As over 9 days. Concentrations of Br remained near the level of the injection for several of the withdrawals during the first 2 days of the experiment (Fig. 1). In contrast, concentrations of $\mathrm{As}(\mathrm{V})$ and $\mathrm{As}(\mathrm{III})$ dropped markedly within the first day to $14 \%$ and $31 \%$ of their initial level, respectively, and declined further during subsequent days. 
Batch experiments were conducted to support the field experiments by further characterizing adsorption of $\mathrm{As}(\mathrm{III})$ and $\mathrm{As}(\mathrm{V})$ using sands and groundwater from the same brown aquifer. The sorption capacity of brown sands freshly collected from drill cuttings is very high $\left(40,000 \mu \mathrm{g} \mathrm{kg}^{-1}\right)$ and follows a Langmuir isotherm (Fig. 2). The resulting adsorption constant, $\mathrm{K}$, is therefore effectively equal to the more commonly used partitioning coefficient, $\mathrm{K}_{\mathrm{d}}\left(\mathrm{L} \mathrm{kg}^{-1}\right.$, i.e. the ratio of adsorbed As to dissolved As at equilibrium). Over the entire range of As additions up to 32,000 $\mu \mathrm{g} \mathrm{L}^{-1}$, the mean $\mathrm{K}$ for both $\mathrm{As}(\mathrm{III})$ and $\mathrm{As}(\mathrm{V})$ is $20 \mathrm{~L} \mathrm{~kg}^{-1}$, and somewhat higher at concentrations below $3,000 \mu \mathrm{g} \mathrm{L}^{-1}(\sim 30$ and $50 \mathrm{~L}$ $\mathrm{kg}^{-1}$ for $\mathrm{As}(\mathrm{III})$ or $\mathrm{As}(\mathrm{V})$, respectively, Fig. 2). Measurement of adsorption over time indicates that rapid adsorption was followed by a slower approach to equilibrium (Supplementary Information). The result is best described by rapid adsorption for $\sim 25 \%$ of the sites $\left(\mathrm{x}_{\mathrm{f}}\right)$ and 50 -fold slower adsorption for the remaining sites. Similar two-step sorption behaviour has been observed for As in other systems ${ }^{19-21}$.

A simple model that takes into account the spatial distribution of the injected As in groundwater and aquifer sands is required to relate batch adsorption parameters to the pushpull experiments. This model assumes homogeneous plug flow and Langmuir adsorption, and accounts for the stepwise withdrawal (Supplementary Information). Standard analytical solutions are not appropriate as they assume continuous pumping ${ }^{22,23}$. The field experiments indicate a conservative range of $\mathrm{K}_{\mathrm{d}}$ 's from 1 to $10 \mathrm{~L} \mathrm{~kg}^{-1}$, while the batch experiments provide an upper limit for As adsorption that may occur given sufficiently slow flow conditions. The most conservative approach for estimating in situ As adsorption is to assume that all adsorption sites are equally accessible $\left(\mathrm{x}_{\mathrm{f}}=100 \%\right)$, which results in $\mathrm{K}$ values of $1.8 \mathrm{~L} \mathrm{~kg}^{-1}$ for $\mathrm{As}(\mathrm{V})$ and $0.5 \mathrm{~L} \mathrm{~kg}^{-1}$ for As(III). This model does not fit the data well beyond the second day of the experiment $\left(r^{2}=0.94\right.$ and 0.87 , Fig. 1). Alternatively, two-step adsorption can be assumed by applying the two batch-derived adsorption parameters, $\mathrm{x}_{\mathrm{f}}=$ $25 \%$ or $\mathrm{K}=50 \mathrm{~kg} \mathrm{~L}^{-1}$. When $\mathrm{x}_{\mathrm{f}}$ is set to $25 \%$, the resulting $\mathrm{K}$ values are $5.1 \mathrm{~L} \mathrm{~kg}^{-1}$ for $\mathrm{As}(\mathrm{V})$ and $1.7 \mathrm{~L} \mathrm{~kg}^{-1}$ for $\mathrm{As}(\mathrm{IIII})\left(\mathrm{r}^{2}=0.97\right.$ and 0.96 , Fig. 1); these values are much lower than observed in the batch experiments (Table S8). When $\mathrm{K}$ is set to $50 \mathrm{~L} \mathrm{~kg}^{-1}$, the high end estimate from the $\mathrm{As}(\mathrm{V})$ batch experiments, the best model fit is achieved when $\mathrm{x}_{\mathrm{f}}=3 \%$ and slow adsorption sites comprised $97 \%$ of the total adsorption sites $\left(r^{2}=0.97\right.$, Fig. 1$)$, modestly higher than the fraction of less accessible adsorption sites in other heterogeneous flood plain aquifers (70 to 90\%) that have been attributed to the presence of fine material, weathering, and sand compaction ${ }^{24,25}$. When applying this $\mathrm{x}_{\mathrm{f}}$ to the As(III) push-pull experiment, the calculated $\mathrm{K}$ is $13 \mathrm{~L} \mathrm{~kg}^{-1}\left(\mathrm{r}^{2}=0.99\right.$, Fig. 1), which approaches the As(III) batch $\mathrm{K}$ of $30 \mathrm{~L}$ $\mathrm{kg}^{-1}$. Taken together, the lower $\mathrm{x}_{\mathrm{f}}$ and $\mathrm{K}$ values estimated here suggest that the limited duration and relatively rapid flow induced during the push-pull tests limited adsorption compared to the shaken slurries used in the batch experiments. Similar high adsorption estimates in batch studies $\left(\mathrm{K}_{\mathrm{d}} \mathrm{s}\right.$ ranging from 35 to $\left.70 \mathrm{~L} \mathrm{~kg}^{-1}\right){ }^{17,26}$ and lower estimates derived indirectly from field observations $\left(\mathrm{K}_{\mathrm{d}} \mathrm{S}\right.$ ranging from 1 to $\left.4 \mathrm{~L} \mathrm{~kg}^{-1}\right){ }^{27}$ have been observed in multiple locations.

Sediment mineralogy considerably affects As adsorption and thus aquifer protection. The distribution of oxidized brown and reduced gray sediments associated with low-As, deep groundwater in the Bengal Basin is variable and not well-documented 9, 10, 28 . Batch studies 
of shallow, high-As gray sediment indicate $\mathrm{K}_{\mathrm{d}}$ values between 1 and $6 \mathrm{~L} \mathrm{~kg}^{-1}$ 2, 29, 30 (see also Supplementary Information), although a push-pull test carried out in high-As gray sands suggests that little As adsorption may occur above a concentration of $100 \mu \mathrm{g} \mathrm{L}^{-1} 31$. Infiltration of reducing shallow groundwater may also result in the reduction of $\mathrm{Fe}$ oxyhydroxides (converting brown sands to gray) and potentially releasing bound As 26,32 , however these mechanisms are likely secondary to adsorption. Given the likely lower adsorption on deeper gray sediments, we conservatively assume that the lower adsorption $\left(K_{d}\right.$ of 1$)$ is characteristic of the majority of the deeper aquifer zones, though the spatial distribution of sorption parameters is currently unknown.

\section{Basin-scale modelling of As transport}

The adsorption properties of aquifer sands determined experimentally can be incorporated into transport models to identify regions of the Bengal Basin most at risk of contamination. The MODFLOW-based advective flow model of Michael and Voss ${ }^{13,33,34}$ was modified to include advective-dispersive solute transport and linear As adsorption $\left(\mathrm{K}_{\mathrm{d}}\right)$ by using MT3DMS ${ }^{35,36}$, allowing for the calculation of As concentrations and depth-variable sorption. Within the source region where groundwater As concentrations are elevated in shallow aquifers 2,13 , initial concentration is constant $\left(C_{0}=1\right)$ in the upper $50 \mathrm{~m}$. Sorption is simulated only at depths $>95 \mathrm{~m}$, with retardation factors of 14 and 130 representing $\mathrm{K}_{\mathrm{d}}$ values of 1.2 and $12 \mathrm{~L} \mathrm{~kg}^{-1}$, which are the average of the most conservative estimates of $\mathrm{As}(\mathrm{III})$ and $\mathrm{As}(\mathrm{V})$ adsorption from the push pull experiments and an order of magnitude greater. We consider pumping from deep aquifers to be unsustainable, i.e. at risk of contamination, when predicted As exceeds $10 \%$ of the upper aquifer concentrations in $<1,000$ years at $162 \mathrm{~m}$ depth, i.e. when $\mathrm{C} / \mathrm{C}_{0}=0.1$ is $12 \mathrm{~m}$ below the top of the deeper pumping zone. In the district with the highest average As concentration in shallow groundwater ${ }^{2}$, the threshold would be reached on average at $37 \mu \mathrm{g} \mathrm{L}^{-1}$. The time span considered is longer than the practical management scale, but this allows for uncertainty and variability in local geochemical and hydrogeologic conditions. Adsorption experiments indicate that deeper sediments have a $\mathrm{K}_{\mathrm{d}}$ of at least $1 \mathrm{~L} \mathrm{~kg}^{-1}$. The protective effect of this weak As adsorption compared to the no-adsorption scenario $\left(\mathrm{K}_{\mathrm{d}}\right.$ of $\left.0 \mathrm{~L} \mathrm{~kg}^{-1}\right)$ is illustrated with maps of $\mathrm{C} / \mathrm{C}_{0}>0.1$ after 1,000 years within the deep pumping zone (Fig. 3). Three water use scenarios were simulated using the domestic and irrigation pumping rates of Michael and Voss ${ }^{33}$. Pumping rates were distributed based on district population and irrigation extents; estimated total irrigation pumping is 10 -fold greater than current domestic pumping rates $\left(0.210 \mathrm{~m} \mathrm{yr}^{-1}\right.$ compared to $\left.0.019 \mathrm{~m} \mathrm{yr}^{-133}\right)$. Shallow domestic pumping was simulated from 10-50 m, shallow irrigation pumping from 50 to $100 \mathrm{~m}$, and deep pumping from 150 to $200 \mathrm{~m}$ depth. In the two 'split' scenarios (S), irrigation pumping is shallow, while domestic pumping is deep with an estimated current rate of $50 \mathrm{~L} \mathrm{person}^{-1} \mathrm{day}^{-1} 33,37$ (SC) and a possible future rate of $200 \mathrm{~L}_{\text {person }}{ }^{-1} \mathrm{day}^{-1}(\mathrm{SH})$, which was based on a quadrupling of current usage and is in line with the average domestic usage in Asia in 2000 $\left(171 \mathrm{~L}_{\text {person }}{ }^{-1} \mathrm{day}^{-1}{ }^{37}\right)$. In the 'deep' scenario, both irrigation and domestic pumping are deep and at current rates (DC). In the 'split' pumping scenario with current domestic usage (SC), adsorption increases the area with sustainable deeper, low-As groundwater from $44 \%$ (SC0) of the affected region without retardation to $99 \%$ (SC1) with weak adsorption (Fig. 
3). Even with high domestic water use (SH), low-As water is still available for $91 \%$ of the high-As area when there is weak adsorption (SH1), but only for $16 \%$ of the area without As adsorption (SH0). While As sorption is still protective in the 'deep' irrigation pumping scenario (DC), the simulated area that is sustainable is significantly reduced, with only $8 \%$ of the area sustainable with no sorption (DC0) and $37 \%$ with weak sorption (DC1).

Additional simulations suggest that increasing $\mathrm{K}_{\mathrm{d}}$ to $12 \mathrm{~L} \mathrm{~kg}^{-1}$, which may be appropriate for some sediments based on our adsorption isotherms, adds a considerable measure of protection, with 100\% of the affected area in the 'split' scenarios (SC10 and SH10) and 96\% of the area in the 'deep' scenario (DC10) remaining low-As over time (Supplementary Information).

The results from physically- and chemically-homogeneous basin-scale simulations provide understanding of effects of pumping and sorption on overall flow and transport behaviour and indicate regional trends resulting from basin geometry. Quantitative inferences about specific locations require knowledge and incorporation of site-specific parameters and heterogeneity (see ref 34 for more information). However, the simulations do suggest that some regions are particularly vulnerable to contamination based solely on their location within the basin. Where the basin is shallow, the flow paths connecting the contaminated shallow aquifers to the deeper aquifer zones are short, thus making these areas more vulnerable. For example, simulated As concentrations are high in a portion of northern West Bengal and west-central Bangladesh in $<1,000$ years in the deep pumping scenario, even with adsorption (Fig. 3). Another concern is areas where long flow paths still originate within the high As region and connect the shallow and deeper aquifers, as is found in southcentral Bangladesh. Breakthrough of high-As water in these and other areas may also be due to factors that were not incorporated in the model, such as high-capacity pumping wells, improperly installed or broken well casings, and hydrogeologic and geochemical heterogeneity.

We investigate specifically the sensitivity of the SC1 scenario to local increases in vertical hydraulic conductivity due to fewer than average layers of fine-grained sediment that are oriented horizontally. On the basin-scale, vertical flow is increased and results in larger areas of contamination. For anisotropy values of 1,000:1 and 100:1, the areas where deep domestic pumping is estimated to be sustainable are reduced to $89 \%$ and $52 \%$, respectively, compared to $99 \%$ for the standard model anisotropy of 10,000:1. Such low anisotropy is not likely to occur everywhere in the basin, but there are regions where low-permeability horizontal layers may be missing, including our study location ${ }^{9}$. This and other uncertainties motivated the conservative timescale and adsorption coefficients used in the modelling.

\section{Implications}

The depth at which wells are screened to access low-As groundwater depends on many factors, including cost and sediment lithology. While some deep well installations have targeted the brown, oxidized sediment for their low-As groundwater ${ }^{7,38}$, wells are often screened only a few meters into such oxidized sediments, despite a government 
recommendation to install wells below a clay layer. We illustrate the protective effect of greater sediment thickness with breakthrough curves at several depths (Fig. 4) at a specific location in central Bangladesh that is vulnerable to downward As migration. At this location, flow paths are downward and travel times are short in both the deep and split pumping scenarios (DC and SC). An intermediate depth of $162 \mathrm{~m}$ was used in the vulnerability maps (Fig. 3) and breakthrough occurs in $<1,000$ years for the no adsorption 'split' pumping scenario (SC0). Breakthrough is twice as fast when the depth into adsorbing sediments is reduced by $50 \mathrm{~m}$ whereas increasing depth by $50 \mathrm{~m}$ delayed breakthrough by a factor of 5 (Fig. 4). When adsorption is included (SC1), the delay of breakthrough is even greater, with breakthrough occurring more than 5 -fold slower at $162 \mathrm{~m}$ than it does at $112 \mathrm{~m}$. Drawing water from beyond the shallowest possible depth therefore offers considerably more protection against intrusion of shallow high-As water, but must be weighed against the increased installation and operation costs, greater drawdowns, and decreased water yields of deeper wells.

The combination of in situ field measurements with basin-scale modelling presented in this study shows that As adsorption on deeper sediments significantly impedes As migration, allowing for the provision of low-As drinking water to a majority of the As-affected areas of Bangladesh for the foreseeable future. This suggests that the high As concentrations observed in some isolated deep wells may not be the result of widespread contamination, but that well construction quality and naturally occurring groundwater As at depth must be considered as possible causes. Modelling indicates that greater withdrawals due to increased domestic use are unlikely to trigger contamination of deep groundwater by As in most of the Bengal Basin. Caution is needed, however, as piped water supplies for growing municipalities are developed, since this analysis considers only spatially-distributed pumping by millions of hand pumps. High-capacity pumping wells could facilitate local deep groundwater contamination. Our results also indicate that most of the Bengal Basin is highly vulnerable to downward migration of high-As groundwater caused by increased withdrawals of deeper groundwater for irrigation, even with the protective effect of sorption. The use of low-As deep groundwater for irrigation should therefore be discouraged, particularly in the areas that are vulnerable to As contamination under domestic-only withdrawal scenarios ( $\mathrm{SC}$ and $\mathrm{SH}$ ). Because irrigating rice paddies with high-As groundwater can have adverse effects ${ }^{8}$, alternative sources of irrigation water as well as farming less water-intensive crops should be considered. Our study highlights particular areas and pumping scenarios where the risk of downward migration of high-As groundwater is elevated. These findings can be used to prioritize both monitoring and water-use management of deeper aquifers. The many deep community wells currently in use throughout the country clearly need to be tested periodically to prevent renewed exposure to As.

\section{Methods Summary}

The As adsorption push-pull tests were conducted in two wells, for As(III) and As(V), using groundwater from a third well with a similar geochemical composition and all were screened at $60 \mathrm{~m}$ (Supplementary Information). To limit the geochemical alteration of the groundwater, a concentrated solution of As and $\mathrm{Br}$ was dynamically added to $\sim 1,000$ litres 
of low-As groundwater as it was pumped from the source well into the receiving well $\sim 10$ $\mathrm{m}$ away, such that the injected water contained $\sim 200 \mu \mathrm{g} \mathrm{L}-1$ of As(III) or As(V) and $\sim 50$ $\mathrm{mg} \mathrm{L}^{-1} \mathrm{Br}$. An inflation packer (Solinst) was deployed to limit dilution within the well casing. Adsorption was monitored through 21 individual "pulls" of $100 \mathrm{~L}$ over 9 days.

The Br only push-pull test employed two separate wells, screened at $65 \mathrm{~m}$ and $10 \mathrm{~m}$ apart, at the same location and injected $540 \mathrm{~L}$ of deep groundwater with $130 \mathrm{mg} \mathrm{L}^{-1}$ of $\mathrm{Br}$, followed by $80 \mathrm{~L}$ of groundwater without tracer. After 2 days, $910 \mathrm{~L}$ of groundwater was continuously pumped out.

Batch experiments were conducted on freshly collected drill cuttings and groundwater and the slurries were prepared in the field under near anaerobic conditions within a few hours of collection. Adsorption isotherms were constructed with As additions ranging from 440 to $32,000 \mu \mathrm{g} \mathrm{L}^{-1}$ and sampled after 145 hours. Kinetic parameters were determined from monitoring a 3,000 $\mu \mathrm{g} \mathrm{L}^{-1}$ addition of As(III) over 400 hours.

Arsenic adsorption was described using a Langmuir model with a single site type. The kinetics of adsorption was modelled by a two-step adsorption process in which a portion $\left(\mathrm{x}_{\mathrm{f}}\right)$ of sites react rapidly with solution, while residual sites $\left(1-\mathrm{x}_{\mathrm{f}}\right)$ have equivalent reactivity but react more slowly, presumably due to diffusion. This division of sites could reflect differences in adsorption sites themselves or the physically restricted access to some sites due to intra-granular or immobile porosity. The push-pull experiments were modelled assuming homogeneous plug flow through concentric rings, each with $100 \mathrm{~L}$ of groundwater. Since the time between "pulls" is large (from 1 to 24 hours), the resting time was divided into 20 equal-sized time steps. The simplification to plug flow is supported by the push-pull test at the same site with only Br tracer that determined dispersivity in the aquifer was small, only $0.5 \mathrm{~cm}$ over the $70 \mathrm{~cm}$ radius penetrated by the tracer, and $90 \%$ of the injected $\mathrm{Br}$ was recovered when the injected volume was removed $\left(\mathrm{V}=\mathrm{V}_{0}\right)$. For the longer duration push-pull experiments with $\mathrm{As},>75 \%$ of the injected $\mathrm{Br}$ was recovered when $\mathrm{V}=\mathrm{V}_{0}$. Because our model neglects dispersion, we constrain our model fitting to the early part of the experiment when samples were only marginally affected by these processes $\left([\mathrm{Br}] /[\mathrm{Br}]_{0}<0.85\right)$. The first sampling point was ignored because the concentrations are changing so rapidly that small timing differences at this point significantly altered the fit of the other data; best parameter fit was achieved by minimizing the least square differences between modelled and measured groundwater As concentrations. The sensitivity of model results to the box size was tested using a model with 10 -fold smaller boxes and this did not substantially change results.

The Bengal Basin groundwater model was modified from the model of Michael and $\operatorname{Voss}^{13}, 33,34$. Transport was simulated using an initial concentration $\left(\mathrm{C}_{0}=1\right)$ in the upper 50 $\mathrm{m}$ and a constant concentration of 1 at the ground surface as a normalized representation of variable As concentrations, of which average As concentration of districts within the affected region of Bangladesh range from 50 to $366 \mu \mathrm{g} \mathrm{L}^{-12}$. Model geometry and flow parameters, homogeneous over the basin, were identical to those estimated as the 'base case' model of Michael and Voss ${ }^{34}$, with a horizontal hydraulic conductivity of $5 \times 10^{-4} \mathrm{~m} \mathrm{~s}^{-1}$, a vertical hydraulic conductivity of $5 \times 10^{-8} \mathrm{~m} \mathrm{~s}^{-1}$, and a porosity of 0.2 . The longitudinal 
dispersivity value of $100 \mathrm{~m}$ was chosen as small as possible on the coarse $(5 \mathrm{~km} \times 5 \mathrm{~km})$ grid while minimizing errors and preventing excessive simulation times; this value is consistent with literature values for systems with similar spatial scale 39,40 . Transverse dispersivity in the horizontal direction was $0.1 \mathrm{~m}$ and in the vertical direction $0.01 \mathrm{~m}$. The sensitivity of model results to grid spacing and numerical solver was tested. Doubling the spatial discretization in the vertical and horizontal directions did not substantially change results or improve convergence, though it should be noted that even $2.5 \mathrm{~km} \times 2.5 \mathrm{~km}$ cells are very large compared to the scale of solute transport processes, so this regional study may exaggerate dispersion. The numerical solver that best minimized numerical dispersion and oscillation and mass balance errors in this case was third-order TVD ${ }^{36}$.

\section{Supplementary Material}

Refer to Web version on PubMed Central for supplementary material.

\section{Acknowledgments}

Columbia University and the University of Dhaka's research in Araihazar has been supported since 2000 by NIEHS Superfund Basic Research Program grant NIEHS 5 P42 ES010349. Undergraduate student support was received from Barnard College and the Earth Institute at Columbia University. The authors thank Leonard Konikow and Clifford Voss (U.S. Geological Survey) for modelling advice and Ho Chit Siu for the grain size analysis (Bronx Science High School). This is Lamont-Doherty Earth Observatory contribution number 7496.

\section{References}

1. Ravenscroft, P.; Brammer, H.; Richards, K. Arsenic Pollution: A Global Synthesis. WileyBlackwell; 2009.

2. BGS/DPHE (British Geological Survey, Dept. of Public Health Engineering, Bangladesh). Arsenic Contamination of Groundwater in Bangladesh, Final Report. British Geological Survey; Keyworth, UK: 2001.

3. BBS/UNICEF (Bangladesh Bureau of Statistics/ United Nations Children's Fund). Bangladesh National Drinking Water Quality Survey of 2009. Dhaka, Bangladesh: 2011.

4. Fendorf S, Michael HA, van Geen A. Spatial and Temporal Variations of Groundwater Arsenic in South and Southeast Asia. Science. 2010; 328:1123-1127.10.1126/science.1172974 [PubMed: 20508123]

5. Ahmed MF, et al. Epidemiology: Ensuring Safe Drinking Water in Bangladesh. Science. 2006; 314:1687-1688.10.1126/science.1133146 [PubMed: 17170279]

6. DPHE/JICA (Dept. of Public Health Engineering, Bangladesh, Japan International Cooperation Agency). Report on Situation Analysis of Arsenic Mitigation, 2009. Dhaka, Bangladesh: 2010.

7. van Geen A, et al. Monitoring 51 community wells in Araihazar, Bangladesh, for up to 5 years: Implications for arsenic mitigation. Journal of Environmental Science and Health Part A-Toxic/ Hazardous Substances \& Environmental Engineering. 2007; 42:1729-1740.

8. Brammer H, Ravenscroft P. Arsenic in groundwater: A threat to sustainable agriculture in South and South-east Asia. Environment International. 2009; 35:647-654.10.1016/j.envint.2008.10.004 [PubMed: 19110310]

9. Zheng Y, et al. Geochemical and hydrogeological contrasts between shallow and deeper aquifers in two villages of Araihazar, Bangladesh: Implications for deeper aquifers as drinking water sources. Geochimica et Cosmochimica Acta. 2005; 69:5203-5218.

10. Burgess WG, et al. Vulnerability of deep groundwater in the Bengal Aquifer System to contamination by arsenic. Nature Geoscience. 2010; 3:83-87.10.1038/ngeo750 
11. Chakraborti D, et al. Status of groundwater arsenic contamination in the state of West Bengal, India: A 20-year study report. Molecular Nutrition \& Food Research. 2009; 53:542-551.10.1002/ mnfr.200700517 [PubMed: 19382148]

12. Mukherjee A, et al. Elevated arsenic in deeper groundwater of the western Bengal basin, India: extent and controls from regional to local scale. Applied Geochemistry. 2011; 26:600-613.

13. Michael HA, Voss CI. Evaluation of the sustainability of deep groundwater as an arsenic-safe resource in the Bengal Basin. Proceedings of the National Academy of Sciences of the United States of America. 2008; 105:8531-8536.10.1073/pnas.0710477105 [PubMed: 18562284]

14. Dixit S, Hering JG. Comparison of arsenic(V) and arsenic(III) sorption onto iron oxide minerals: Implications for arsenic mobility. Environmental Science \& Technology. 2003; 37:4182-4189. [PubMed: 14524451]

15. Jonsson J, Sherman DM. Sorption of As(III) and As(V) to siderite, green rust (fougerite) and magnetite: Implications for arsenic release in anoxic groundwaters. Chemical Geology. 2008; 255:173-181.10.1016/j.chemgeo.2008.06.036

16. Smedley PL, Kinniburgh DG. A review of the source, behaviour and distribution of arsenic in natural waters. Applied Geochemistry. 2002; 17:517-568.

17. Stollenwerk KG, et al. Arsenic attenuation by oxidized aquifer sediments in Bangladesh. Science of the Total Environment. 2007; 379:133-150. [PubMed: 17250876]

18. Radloff KA, et al. Mobilization of arsenic during one-year incubations of grey aquifer sands from Araihazar, Bangladesh. Environmental Science \& Technology. 2007; 41:3639-3645. [PubMed: 17547190]

19. Fuller CC, Davis JA, Waychunas GA. Surface-chemistry of Ferrihydrite. 2. Kinetics of arsenate adsorption and coprecipitation. Geochimica et Cosmochimica Acta. 1993; 57:2271-2282.

20. Raven KP, Jain A, Loeppert RH. Arsenite and arsenate adsorption on ferrihydrite: Kinetics, equilibrium, and adsorption envelopes. Environmental Science \& Technology. 1998; 32:344-349.

21. Selim HM, Zhang H. Arsenic adsorption in soils: Second-order and multireaction models. Soil Science. 2007; 172:444-458.

22. Schroth MH, Istok JD, Haggerty R. In situ evaluation of solute retardation using single-well pushpull tests. Advances in Water Resources. 2001; 24:105-117.

23. Cassiani G, Burbery LF, Giustiniani M. A note on in situ estimates of sorption using push-pull tests. Water Resources Research. 2005; 41:W03005.

24. Haggerty R, Gorelick SM. Multiple-rate mass-transfer for modeling diffusion and surface-reactions in media with pore-scale heterogeneity. Water Resources Research. 1995; 31:2383-2400.

25. Wood WW, Kraemer TF, Hearn PP. Intragranular diffusion - An important mechanism influencing solute transport in clastic aquifers. Science. 1990; 247:1569-1572. [PubMed: 17782812]

26. Dhar RK, et al. Microbes enhance mobility of arsenic in Pleistocene aquifer sand from Bangladesh. Environmental Science \& Technology. 2011; 45:2648-2654. [PubMed: 21405115]

27. McArthur JM, et al. Migration of As, and ${ }^{3} \mathrm{H} /{ }^{3} \mathrm{He}$ ages, in groundwater from West Bengal: Implications for monitoring. Water Research. 2010; 44:4171-4185.10.1016/j.watres.2010.05.010 [PubMed: 20542311]

28. Goodbred SL, Kuehl SA, Steckler MS, Sarker MH. Controls on facies distribution and stratigraphic preservation in the Ganges-Brahmaputra delta sequence. Sedimentary Geology. 2003; 155:301-316.

29. Jung HB, Charette MA, Zheng Y. Field, Laboratory, and Modeling Study of Reactive Transport of Groundwater Arsenic in a Coastal Aquifer. Environmental Science \& Technology. 2009; 43:53335338.10.1021/es900080q [PubMed: 19708362]

30. van Geen A, et al. Flushing history as a hydrogeological control on the regional distribution of arsenic in shallow groundwater of the Bengal Basin. Environmental Science \& Technology. 2008; 42:2283-2288. [PubMed: 18504954]

31. Harvey CF, et al. Arsenic mobility and groundwater extraction in Bangladesh. Science. 2002; 298:1602-1606. [PubMed: 12446905]

32. Polya D, Charlet L. Nature Geoscience. 2009; 2:383-384.10.1038/ngeo537 
33. Michael HA, Voss CI. Controls on groundwater flow in the Bengal Basin of India and Bangladesh: regional modeling analysis. Hydrogeology Journal. 2009; 17:1561-1577.10.1007/ s10040-008-0429-4

34. Michael HA, Voss CI. Estimation of regional-scale groundwater flow properties in the Bengal Basin of India and Bangladesh. Hydrogeology Journal. 2009; 17:1329-1346.10.1007/ s10040-009-0443-1

35. Harbaugh AW, Banta ER, Hill MC, McDonald MG. MODFLOW-2000, the U. S. Geological Survey modular ground-water model -- User guide to modularization concepts and the GroundWater Flow Process. Vol U S Geological Survey Open-File Report 00-92. 2000

36. Zheng, C.; Wang, PP. MT3DMS: A modular three-dimensional multispecies model for simulation of advection, dispersion and chemical reactions of contaminants in groundwater systems; Documentation and User's Guide. U.S. Army Engineer Research and Development Center; Vicksburg, MS: 1999.

37. Gleick, PH., et al. The World's Water: 2008-2009. Island Press; Washington, D.C.: 2009.

38. von Bromssen M, et al. Targeting low-arsenic aquifers in Matlab Upazila, Southeastern Bangladesh. Science of the Total Environment. 2007; 379:121-132.10.1016/j.scitotenv. 2006.06.028 [PubMed: 17113133]

39. Gelhar LW, Welty C, Rehfeldt KR. A critical review of data on field-scale dispersion in aquifers. Water Resources Research. 1992; 28:1955-1974.

40. Neuman SP. Universal scaling of hydraulic conductivities and dispersivities in geologic media. Water Resources Research. 1990; 26:1749-1758. 


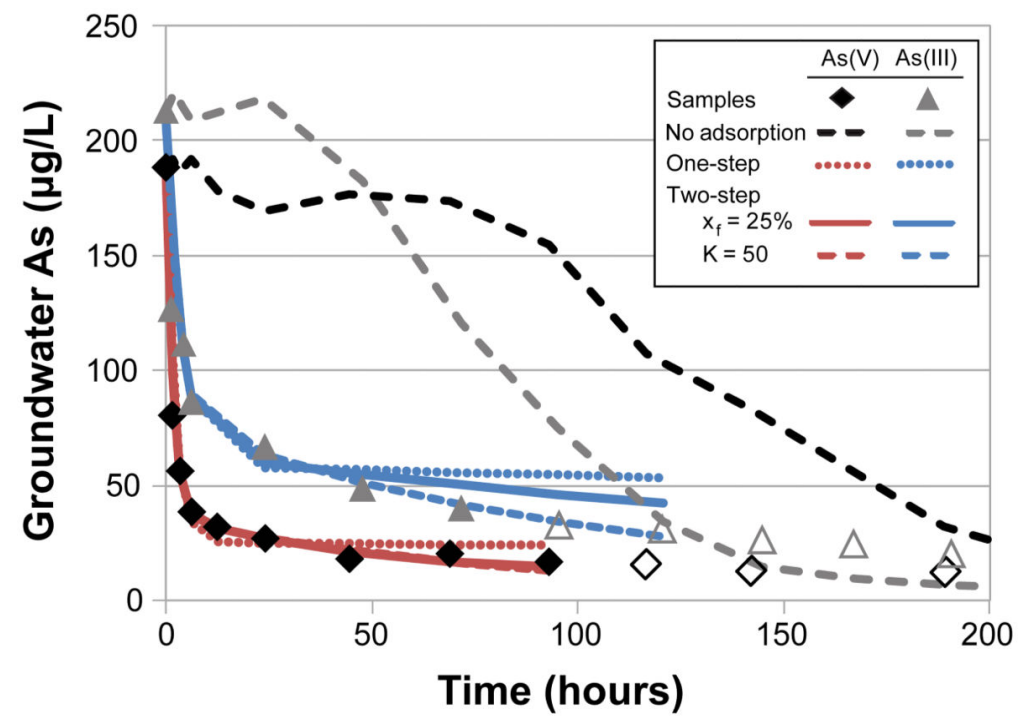

Fig. 1. Arsenic adsorption in push-pull tests

The rapid adsorption of As followed by a slow decrease towards equilibrium is observed in the As(V) and As(III) push-pull tests. In $24 \mathrm{hrs,} 70 \%$ of As(III) and $85 \%$ of As(V) were adsorbed with most of the remaining As adsorbing over $200 \mathrm{hrs}$. Dashed lines indicate [As] if there was no adsorption (determined from [Br]). Samples with significant dilution (e.g. $\left.[\mathrm{Br}] /[\mathrm{Br}]_{0}<0.85\right)$ are shown as unfilled symbols and were not used for model fitting. Best fits are shown for three scenarios -the one-step model, and 2 two-step models based on the batch results, where $\mathrm{x}_{\mathrm{f}}$ was set to $25 \%$ or where the $\mathrm{As}(\mathrm{V}) \mathrm{K}$ was set to $50 \mathrm{~L} \mathrm{~kg}^{-1}$. 


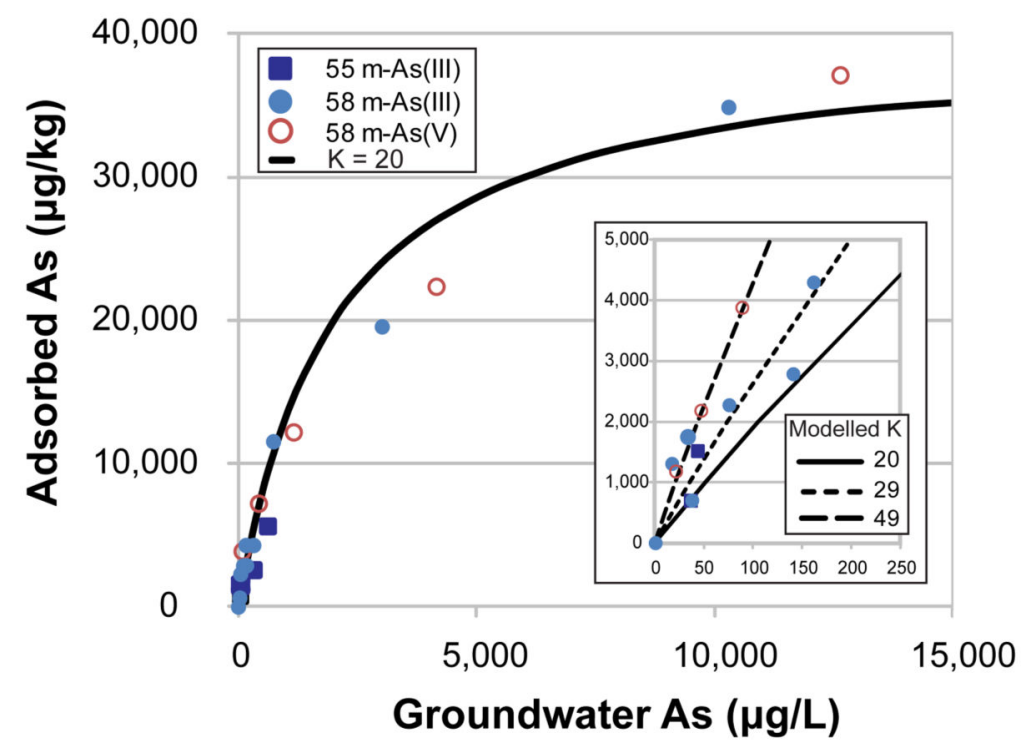

Fig. 2. Arsenic adsorption in batch isotherm experiments

Groundwater spiked with As(III) or As(V) was mixed with cuttings from the brown aquifers and sampled 145 hours later. The solid line indicates the best fit sorption isotherm for brown sediments over the entire range of additions (up to $32,000 \mu \mathrm{g} / \mathrm{L}$ ), while the dashed lines are best fits for As(III) or As(V) additions up to 3,000 $\mu \mathrm{g} / \mathrm{L}$ (29 and $49 \mathrm{~L} \mathrm{~kg}^{-1}$, respectively). The capacity of the brown sediment at $58 \mathrm{~m}$ is $40,000 \mu \mathrm{g} / \mathrm{kg}$. 


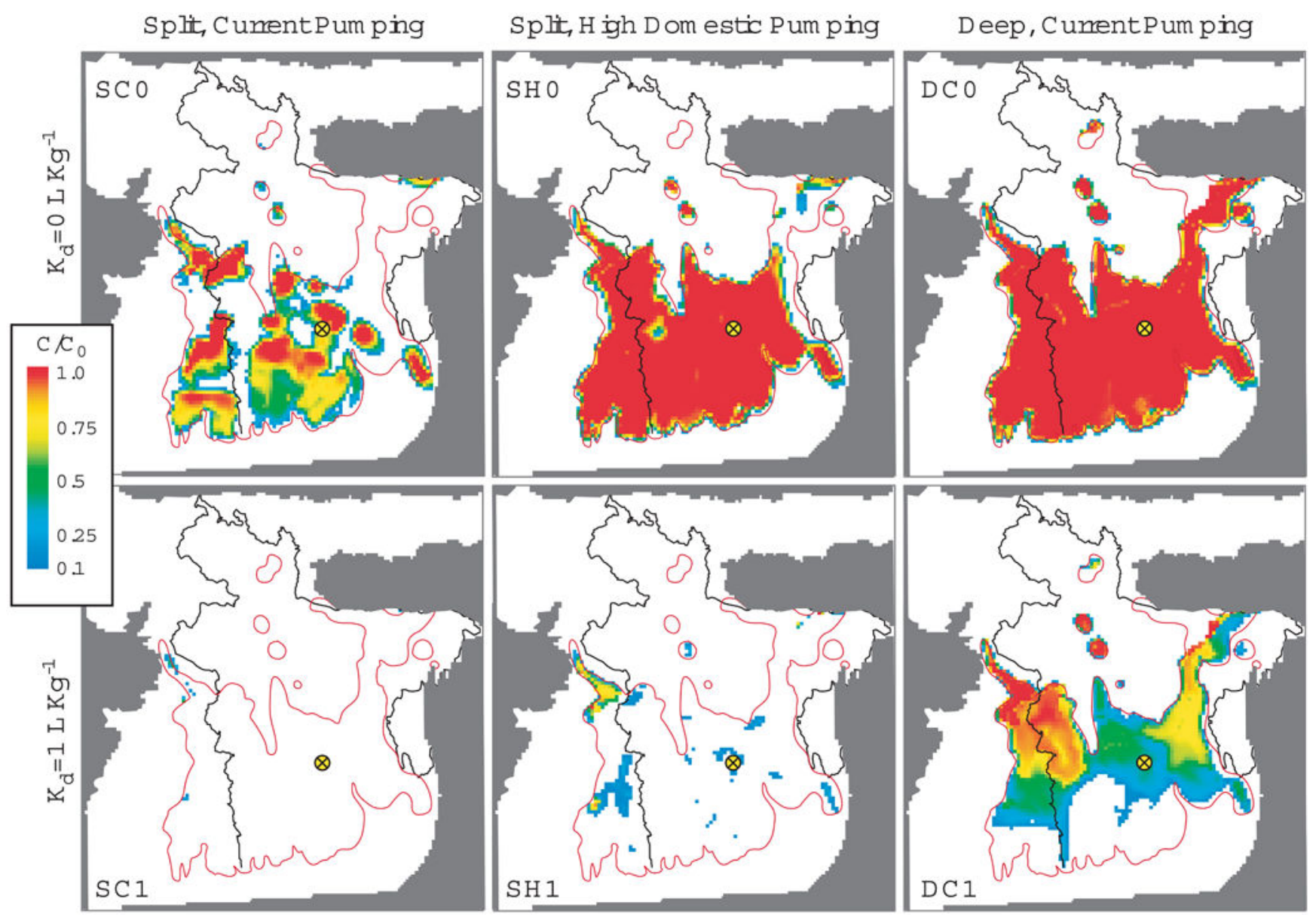

Fig. 3. Areas where deep, low-As groundwater is at risk of contamination

Model boundary is enclosed in gray, Bangladesh border is black, and red lines encircle regions with high-As groundwater in shallow aquifer zones ${ }^{2,13}$. Colour scale indicates simulated [As] for $\mathrm{C} / \mathrm{C}_{0}>0.1$ after $1,000 \mathrm{yr}$ at a depth of $162 \mathrm{~m}$. Modelled [As] is shown for the 3 water use scenarios (SC, SH and D) - 'split' with shallow irrigation and deep domestic pumping at current $\left(50 \mathrm{~L} \mathrm{day}^{-1}\right.$ person $\left.^{-1}, \mathrm{SC}\right)$ or future $\left(200 \mathrm{~L} \mathrm{day}^{-1}\right.$ person $\left.^{-1}, \mathrm{SH}\right)$ rates or 'deep' pumping only (DC) with two retardation factors $\left(\mathrm{K}_{\mathrm{d}}=0\right.$ and $\left.1.2 \mathrm{~L} \mathrm{~kg}^{-1}\right)$. Yellow dot indicates the location of plotted concentrations in Fig. 4. 


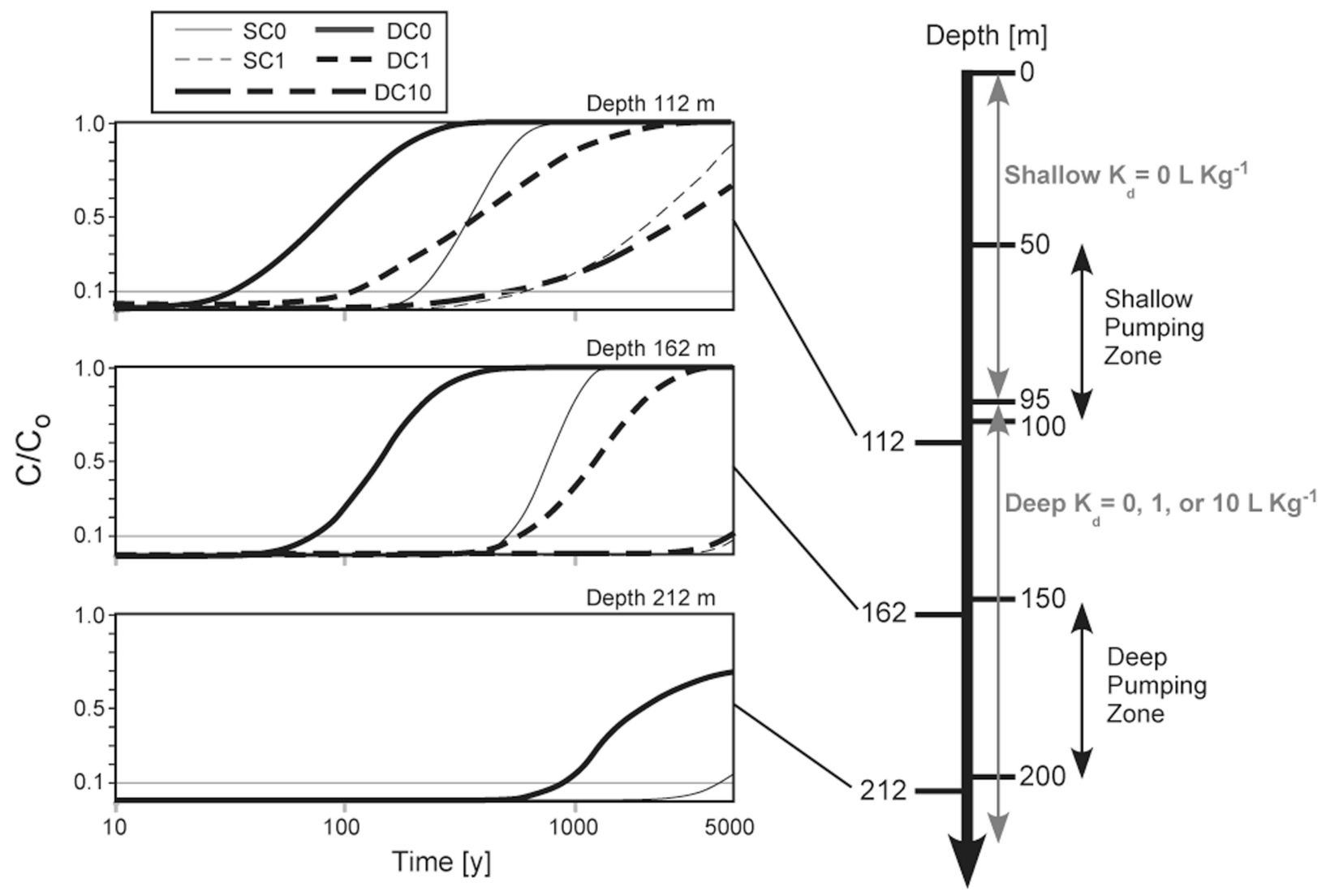

Fig. 4. Simulated groundwater [As] breakthrough by depth

[As] are simulated at 3 depths for one highly-vulnerable location (indicated in Fig. 3) under the current 'split' pumping (SC) and the deep pumping (DC) scenarios. Domestic pumping is simulated within a constant depth range (150 to $200 \mathrm{~m}$ ). Breakthrough curves for no $\left(\mathrm{K}_{\mathrm{d}}=0 \mathrm{~L} \mathrm{~kg}^{-1}\right.$, solid $)$, low $\left(\mathrm{K}_{\mathrm{d}}=1.2\right.$, dashed $)$ and high $\left(\mathrm{K}_{\mathrm{d}}=12\right.$, long dashed $)$ retardation are shown over 5,000 yrs in log scale at 3 depths: $112 \mathrm{~m}$ is near the top of the low-As aquifer zone, $162 \mathrm{~m}$ is in the deep pumping zone, and $212 \mathrm{~m}$ is below it. 